\title{
Education in Risk Management
}

\author{
A European View: Past, Present and Future \\ by Gordon C. A. Dickson*
}

\section{Introduction}

People represent the most important asset we have in risk management, both those who currently practise risk management and those who have aspirations to become the risk managers of the future. Those of us who are concerned about the future of risk management must take time to consider the development of this asset, both for those currently practising and those whom we would like to see moving into the world of risk management in the future.

Education and training, in the widest sense, is about developing this human asset and should not be looked upon as an additional extra in a list of things which we may get round to when we have time. This implies development of those involved in risk management today and ensuring that a flow of good quality candidates into risk management is encouraged.

In many ways, education is the key to the future in;

- Enhancing the recognition of risk management as a management discipline. One of the hallmarks of any profession is the educational provision for its members.

- Unlocking the skills and talents of those involved in risk management.

- Providing the 'best' risk management service to industry.

- Ensuring that there is adequate development of the discipline itself.

- Attracting the right calibre of new entrant to risk management. High quality personnel are more likely to be attracted to a discipline which has a well defined educational pathway to qualification.

- Enabling people to be in a position to respond to the challenges posed by change.

Before moving any further, let us be clear as to what we mean by risk management. There are many definitions and as 'academics' have been responsible for many of them one is reluctant to add to the list. However we must be clear that we are all talking about the same concept. A recent paper in the American Risk and Insurance Association's, Journal

\footnotetext{
* Bowring Professor of Risk Management, Glasgow Polytechnic, Glasgow, Scotland.
} 
of Risk and Insurance, highlighted for me the need to clarify definitions. In a paper entitled "Insurance in the Undergraduate Curriculum" the author inserted a footnote as follows: "The author prefers the traditional word 'insurance' where others might prefer 'risk management". I do not subscribe to the view that insurance and risk management are synonymous. Risk management implies a corporate approach to risk, of which insurance will certainly be a part, but it is a far broader more sophisticated management tool than simply arranging insurance. This broader view of risk management is embraced within the following definition;

The identification, analysis and economic control of those risks which threaten the assets or earning capability of an organisation.

We may not all agree on this definition but it does emphasise the three-fold approach of identification, analysis and control and we can see insurance as having an important part to play as a financial control mechanism.

\section{Risk management education in perspective}

What then is the role of education, what is its relevance, what place should it occupy? To answer this we will have to go back one step to the reason for risk management in the first place, to risk. Risk is at the very core of all that we do. There is little point in debating the merits of risk management education unless we get the problems of risk in perspective and are committed to the need for it itself.

Risk has occupied the headlines much more over recent years. We have had Bhopal, Chernobyl, Piper Alpha, Kings Cross, Zeebrugge. These are the large events which occupy our newspapers and television screens. But they are only the tip of the risk iceberg. Underneath this tip lies the real toll of risk with which those involved in risk management spend their working days. Risk management plays an invaluable role in identifying, measuring and controlling the many risks to which businesses of all forms are exposed.

\section{The practice}

What is actually happening at the moment in the world of risk management education? It may be useful, before we try to answer this question, to preface the comments in two ways.

Firstly, there is a wide variation from country to country in their funding of and general approach to education and training in business. In some countries levies are imposed on companies which are then used for education and training while in others, there is reliance on central funding. The danger is that education and training often ends up with a low profile in many companies. It is not hard to see why this should be so. Education does not seem to produce any short term result in terms of increased income. In periods of high expenses and low profit margins, education and training budgets are often the first to go. This is certainly true during periods of recession, when 'short termism' is even more rampant than normal.

Secondly, whatever we say about education in relation to risk management must be seen against the background of education for that country as a whole. This is an important point which is often overlooked. Professional education builds upon whatever has taken place in the formal education structures of the country and will be influenced by the whole approach to education matters in that country. 
This means, among other points, the number of people who continue to participate in education at high school or final school level, the amount of money a country deems it proper to spend on education and of course the eventual penetration of education into the workplace.

With these comments prefacing what we have to say, can we paint some kind of picture of risk management education?

This is very much a matter of judgement and opinion and therefore open to discussion. It seems to me that seven points could be made. These are by way of observations, some take the form of criticisms while others are simply comments:

1. There is little or no mention of risk and insurance in most formal school education. This is certainly true for the United Kingdom. Children are not exposed to risk and uncertainty and consequently there is the danger that they grow up in the world either expecting certainty or having a very negative view of risk.

2. There is little or no provision for full time post-school education in risk management. Where such education does exist, it is largely dominated by the skills of the particular institution and has not taken the inter-disciplinary route.

3. The professional qualification route is the normal means by which people have sought formal qualification in risk management. This, in many countries has in reality meant a professional qualification in insurance.

4. In-house education and training in risk management is almost non-existent in many companies as the risk management department will be very small and regarded as a specialism.

5. During periods of soft market conditions there is very little motivation for companies to devote monetary resources to the provision of technical risk management skills.

6. The main form of learning has been experiential in the sense that people learned on the job.

7. There is very little international collaboration among those involved in risk management education. The result is that there is no recognised standard for such education and this must be a concern if we are striving after corporate recognition of and acceptability for risk management.

This is by no means an exhaustive list and indeed people may want to take issue with one or all of these observations. They do however represent one view of the current practice of risk management education and form the basis from which we can move on to look at the future.

\section{The future}

The future of risk management education must be linked to the future of the risk business itself. As we look to the end of this century, what do we see? Five features of the business world stand out:

1. The pace of change.

2. Increasing sophistication in risk.

3. Increasing risk awareness and consumerism.

4. There will be a continuing unbundling of insurance services.

5. The world will continue to become smaller. 
If this is to be anything like the pattern of the future as far as risk management is concerned, what shape should risk education take?

The product of this education will be the person who has to deal with this ever changing world of sophisticated risks, unbundled services and so on. What skill will he or she require to equip them for the task? In a recent edition of Risk Management, the publication of the American Risk and Insurance Management Society, there was one suggestion. It was offered by the Chief Executive Officer of Alexander and Alexander Services, Mr. M. Griffith. He said that in order to survive, the risk manager would need:

- Risk assessment skills

- The ability to communicate

- Financial expertise

- Computer skills

- Industry understanding

- Commitment/motivation

- Problem resolution skills

- Interpersonal skills

- The ability to manage management

- Planning skills.

This is a fairly formidable list and no one would take issue with these attributes. The difficulty is that it imagines a kind of superman. How can we best move towards providing some if not all of these skills for the present and succeeding generations of risk managers?

Four criteria for our education in the future are suggested:

- Flexibility

- Availability

- Relevance

- Enjoyable.

\subsection{Flexibility}

Whatever pattern we develop it must be flexible in at least two respects; It must allow students the maximum amount of choice over what they study and enable those responsible for the course to adapt to the ever changing needs of the industry.

This is very much the way in which education is developing. We see it in the formal structures of higher education which allow students to decide on a core curriculum and then select their own pathways to qualifications by studying a number of selected options. We have seen in it many professional bodies as they up-date their qualifications; the Chartered Insurance Institute in the United Kingdom is a recent and good example of this.

All of these comments apply equally to in-house training. There is a certain core knowledge which is essential and then options or modules can be offered in order to cater for individual needs.

\subsection{Availability}

The scheme must be there when people need it. It must be possible to opt in and out of education as the pressures of work vary. It must be possible to proceed at a pace which is reasonable, bearing in mind all the demands placed on busy risk management 
professionals. It must not be viewed that education is only for those who are starting off in the business. We must develop the culture that education is a continuing process and ensure that this education is always available.

The Institute of Risk Management in the United Kingdom, The Insurance Institute of America and certain other Institutes around the world, have endeavoured to do this with their Professional Diplomas in risk management.

\subsection{Relevance}

The education or training which people receive must be seen by them to be relevant to what they know is the real world. There is little point in filling heads with theory which cannot be applied.

In many countries there is a shortage of technically proficient risk management staff. Periods of soft market conditions often mean that technical training is not valued. If the industry is to move forward we do need staff who are capable of responding to the challenges of the changing face of risk.

One of the rather more educational problems is the nature of the subject itself. It really is a combination of a number of different areas of study. The study of risk management incorporates the law, accounting, insurance, statistics, economics, marketing, management and technical subjects such as fire and safety. All of these must be blended together to produce what we know and recognise as risk management. In the language of education, the topic of risk management is inter-disciplinary rather than simply being multi-disciplinary.

\subsection{Enjoyable}

Lastly I would argue that a person's education or training should be enjoyable. There has been the long held view, possibly stronger in Scotland than elsewhere, that education should hurt. Like all good medicines it should be unpleasant. I do not subscribe to this view. It is my belief that the best environment in which to learn is one in which you enjoy the learning experience.

\section{Conclusion}

The future lies with those we will educate and train today. In Europe, the AEAI has recognised the responsibility which professional bodies have to future generations and to the well-being of the discipline itself. There has been active discussion on a plan for a general standard of risk management education and the positive hope is that such a standard will be agreed by member associations in the not too distant future. 